\title{
KESULITAN SISWA SMP BELAJAR KONSEP DAN PRINSIP DALAM MATEMATIKA
}

\author{
Oleh: A.lka Prasasti Abrar \\ Prodi Pendidikan Matematika Jurusan Tarbiyah STAIN Palopo
}

\begin{abstract}
Abstrak:
Kesulitan siswa dalam mempelajari matematika diklasifikasikan ke dalam tiga jenis kesulitan, yaitu kesulitan dalam menggunakan konsep, kesulitan dalam menggunakan prinsip, dan kesulitan dalam menyelesaikan masalah-masalah verbal. Kesulitan dalam menyelesaikan masalah verbal merupakan perluasan dari kesulitan dalam menggunakan konsep dan prinsip.
\end{abstract}

Kata kunci : Kesulitan Belajar, Konsep, Prinsip, Matematika

\section{Pendahuluan}

\section{A. Latar belakang}

Rendahnya hasil belajar matematika merupakan salah satu masalah bagi mutu pendidikan dewasa ini. Hal ini dapat dilihat dari penguasaan bahan ajar oleh siswa, di mana masih jauh dari yang diharapkan. Wardiman Djojonegoro mengungkapkan bahwa penguasaan siswa pada jenjang pendidikan menengah terhadap pendidikan MIPA masih rendah (Usman, 1998). Hal ini menunjukkan bahwa pengajaran matematika sekolah hingga dewasa ini umumnya kurang berhasil.

Upaya untuk mengatasi rendahnya hasil belajar matematika telah dilakukan oleh pemerintah. Seperti penyempurnaan kurikulum, pengadaan buku paket, peningkatan pengetahuan guru-guru melalui penataran, pelatihan-pelatihan, workshop mata pelajaran baik secara regional maupun secara nasional. Selain itu, juga telah dilakukan berbagai penelitian terhadap faktor-faktor yang diduga mempengaruhi belajar matematika. Walaupun berbagai upaya telah dilakukan namun kenyataan menunjukkan bahwa hasil belajar matematika masih jauh dari yang diharapkan.

Rendahnya hasil belajar matematika tersebut, diduga sebagai akibat dari siswa yang mengalami kesulitan ketika sedang mempelajari materi pelajaran matematika. Kesulitan yang muncul mengakibatkan siswa yang bersangkutan sulit 
untuk memahami apa yang sedang dipelajari. Karena itu, Soedjadi (dalam Mulbar, 1988) mengemukakan bahwa kesulitan siswa itu bukan masalah baru, tetapi tidak dapat dipecahkan hanya dalam satu cara, serta memerlukan perhatian yang terus menerus lebih lanjut dikatakan bahwa kesulitan siswa dalam belajar matematika adalah sesuatu yang unik.

Dengan sifat keunikan tersebut, maka kesulitan siswa dapat diduga sangat beragam, ini dipengaruhi oleh potensi yang ada pada masing-masing pribadi (individu). Dalam hal ini guru sangat diharapkan untuk dapat mengantisipasi kerawanan dan kesulitan yang diduga akan muncul, serta berani menentukan dan mengukur bahan pelajaran yang akan diberikan.

Kesulitan siswa dalam belajar matematika tersebut kemungkinan karena siswa tidak atau belum mengetahui cara belajar matematika yang baik. Berkaitan dengan kenyataan ini, Herman Hudoyo (1998) mengatakan bahwa belajar matematika akan berhasil bila proses belajarnya baik, dan peristiwa belajar yang dikehendaki akan tercapai apabila faktor yang mempengaruhi dapat dikelola dengan sebaik-baiknya. Faktor tersebut antara lain, peserta didik, pengajar, sarana dan prasarana serta penilaian.

Di lain pihak, salah satu sifat dari matematika adalah hirarkis, sifat ini menunjukkan bahwa suatu konsep atau prinsip yang mendasar (elementer) umumnya digunakan secara berkesinambungan, sebagai sarana untuk menjelaskan konsep-konsep atau menurunkan prinsipprinsip yang lebih tinggi. Oleh karena itu, akan menjadi suatu hal yang tidak baik, bila siswa tidak menguasai dan memahami konsep dan prinsip dasar. Dengan kata lain, siswa akan mengalami kesulitan memahami konsep dan prinsip pada materi lanjut tersebut. Ketidakberhasilan ini akan memunculkan kesulitan dalam pembelajaran selanjutnya, demikian seterusnya yang akan dialami siswa.

Pelajaran matematika diberikan di jenjang persekolahan dengan harapan dapat menumbuh kembangkan kemampuan-kemampuan umum yang diperlukan siswa untuk menghadapi persolan yang muncul dalam kehidupan mereka di masa mendatang. Kemampuan ini meliputi :

1) Kemampuan menerapkan / menggunakan matematika dalam berbagai bidang 
2) Kemampuan penalaran, meliputi kemampuan melakukan analisis, sintesis, evaluasi dan kemampuan mengkonstruksi suatu model.

3) Kemampuan membedakan yang benar dan yang salah disertai pendapat atau alasan yang logis dan konsisten.

4) Kemampuan mandiri dan kerja keras.

5) Kemampuan memecahkan masalah.

Kemampuan-kemampuan yang dimaksud di atas tidak dapat dicapai sebagaimana yang diharapkan bilamana siswa mengalami hambatan dan kesulitan di tingkat dasar. Kesulitan siswa dalam mempelajari matematika dapat dilihat dari beberapa proses seperti:

1) Kesulitan dalam memahami informasi baru dalam matematika

2) Kesulitan dalam menjawab/ memecahkan masalah dalam matematika.

Selain dari dua kesulitan di atas, kesulitan siswa juga dapat terjadi bila siswa tersebut belum memahami objek matematika yang dipelajarinya seperti konsep dan prinsip dalam matematika.

Memperhatikan kenyataan di atas, kiranya perlu diamati permasalahan mengenai kesulitan siswa terhadap materi matematika yang esensial, khususnya materi pengantar aljabar di kelas I SMP. Bentuk-bentuk aljabar secara implisit telah disisipkan dalam kurikulum sekolah dasar. Namun materi pelajaran aljabar yang dianggap perlu untuk diangkat sebagai makalah untuk mengetahui kesulitan siswa dalam mempelajari dan memahami konsep dan prinsip yang tercakup dalam materi pengantar aljabar.

\section{B. Pembatasan masalah}

Berdasarkan latar belakang yang telah dikemukakan, maka dirumuskan masalah daalam penulisan makalah ini sebagai berikut :

1) Bagaimana gambaran kesulitan siswa kelas I SMP dalam mempelajari konsep pada materi pengantar aljabar?

2) Bagaimana gambaran kesulitan siswa kelas I SMP dalam mempelajari prinsip pada materi pengantar aljabar?

\section{Pembahasan}

\section{A. Kesulitan siswa dalam belajar matematika}

Coney (dalam Mulbar) mengatakan kesulitan siswa dalam mempelajari matematika diklasifikasikan ke dalam 
tiga jenis kesulitan, yaitu kesulitan dalam menggunakan konsep, kesulitan dalam menggunakan prinsip, dan kesulitan dalam menyelesaikan masalah-masalah verbal. Lebih lanjut beliau mengatakan bahwa kesulitan dalam menyelesaikan masalah verbal merupakan perluasan dari kesulitan dalam menggunakan konsep dan prinsip. Kesulitan siswa dalam menggunakan konsep antara lain :

1) Ketidakmampuan untuk mengingat nama secara lisan.

2) Ketidakmampuan menyatakan arti dari istilah yang mewakili konsep tertentu.

3) Ketidakmampuan untuk mengingat satu atau lebih kondisi yang diperlukan bagi suatu objek untuk dinyatakan dengan istilah yang mewakilinya.

4) Ketidakmampuan untuk mengingat suatu kondisi yang cukup bagi suatu objek untuk dinyatakan dengan istilah yang mewakili konsep tersebut.

5) Tidak dapat mengelompokkan objek sebagai contoh suatu konsep dari objek yang bukan contohnya.

6) Ketidakmampuan untuk menyimpulkan informasi dari suatu konsep yang diberikan.

Kesulitan dalam menggunakan konsep dasar menambah kesulitan siswa mempelajari dan menggunakan prinsip. Kesulitan siswa dalam menggunakan prinsip, antar lain:

1) Kesulitan melakukan kegiatan penemuan tentang sesuatu, teliti melakukan perhitungan operasi aljabar.

2) Ketidakmampuan siswa menentukan faktor yang relevan. Akibatnya tidak mampu mengabstraksikan pola-pola.

3) Siswa dapat menyatakan suatu prinsip tetapi kesulitan mengutarakan artinya dan menerapkan prinsip tersebut.

Kemampuan untuk menyelesaikan masalah verbal sangat ditentukan oleh pengetahuan dan kemampuan siswa dalam menggunakan konsep dan prinsip. Apabila seorang siswa tidak mampu memahami arti istilah tersebut, serta mengalami ketidakmampuan seperti yang dipaparkan, maka siswa tersebut tentu akan mengalami kesulitan dalam menyelesaikan masalah-masalah verbal.

Berkaitan dengan hal di atas, maka pada materi pengantar aljabar, kesulitan yang dialami siswa pada umumnya ditandai dengan adanya kesulitan yang sama dari waktu ke waktu. Kenyataan ini menunjukkan bahwa sebagian besar siswa memiliki pemahaman yang sempit mengenai variabel. Berdasarkan kenyataan tersebut, maka 
konsep dan prinsip tertentu perlu mendapat sorotan berkaitan dengan pemahaman siswa dalam mempelajari materi pengantar aljabar di kelas I SMP.

\section{B. Konsep}

Konsep dalam matematika adalah suatu ide abstrak yang memungkinkan seseorang mengklasifikasikan objekobjek atau kejadian dan menentukan apakah objek atau kejadian itu merupakan contoh atau bukan contoh dari ide tersebut. Herman Hudoyo(1998) mengatakan belajar konsep adalah belajar memahami sifat-sifat dari benda konkrit atau peristiwa-peristiwa, untuk dikelompokkan satu jenis.

Konsep dapat dipelajari melalui observasi langsung, seorang anak dapat menggolongkan objek-objek, misalnya dari sekumpulan kalimat matematika yang diberikan, para siswa dapat belajar dengan menggolongkan kalimat-kalimat tersebut dalam kumpulan pernyataan , kesamaan, kalimat terbuka, atau persamaan. Dengan penggolongan itu, siswa akan memperoleh konsep pernyataan, konsep kalimat terbuka dan konsep persamaan contoh konsep yang lain seperti variabel, penyelesain himpunana dan sebagainya.

\section{Prinsip}

Prinsip dalam matematika menyatakan hubungan dua atau lebih. Yang dihubungkan itu mungkin berupa fakta, konsep, operasi atau prinsip lainnya. Peryataan " jika kedua ruas persamaan ditambah dengan suatu bilangan yang sama, maka diperoleh persamaan baru yang mempunyai himpunan penyelesaian yang sama dengan himpunan penyelesaian. Prinsip ini digunakan dengan penyelesaian suatu persamaan. Selain berujud kata-kata, prinsip dapat pula berwujud teorema atau rumus. Contoh prinsip dalam bentuk rumus antara lain rumus kuadrat (rumus $A B C$ ), teorema phythagoras, dan sebagainya.

Prinsip dalam matematika dapat dipelajari dengan proses inkuiri, penemuan terbimbing, diskusi kelompok, penggunaan strategi, pemecahan masalah dan demonstrasi. Untuk memahami suatu prinsip, seseorang harus terlebih dahulu mengetahui memahami konsep-konsep yang tercakup dalam prinsip yang dimaksud.

\section{Materi pengantar aljabar}

Aljabar merupakan suatu bagian yang termuat dalam matematika sekolah. Materi pengantar aljabar meliputi :

1. Operasi hitung pada bentuk aljabar 
2. Kalimat terbuka

3. Persamaan linier dengan satu peubah

4. Pertidaksamaan linier dengan satu peubah.

Rincian tiap-tiap materi disajikan sebagai berikut :

1. Operasi hitung pada bentuk aljabar

a. Menggunakan penjumlahan dan perkalian bilangan bulat pada bentuk aljabar

1) Membahas arti dari $2 x$ dan $x^{2}$

2) Mengenal factor perkalian, koefisien suku, dan suku sejenis.

3) Menentukan KPK dan FPB bentuk aljabar suku tunggal.

4) Menyatakan perkalian sebagai suatu konstanta dengan suku dua sebagai jumlah.

5) Mensubtitusi bilangan pada huruf di suku banyak.

b. Menyelesaikan soal cerita yang menggunakan bilangan bulat.

2. Kalimat terbuka

a. Membahas pengertian :

6) Kalimat benar dan kalimat salah

7) Kalimat terbuka, peubah, konstanta melalui contoh.

b. Menentukan himpunan penyelesaian dari suatu kalimat.

3. Persamaan linier dengan satu peubah

a. Membahas pengertian persamaan, penyelesaian suatu persamaan dengan satu peubah.

b. Menentukan himpunan penyelesaian satu persamaan dengan cara subtitusi.

c. Menerjemahkan kalimat terbuka yang berbentuk cerita ke kalimat matemátika.

d. Menyelesaikan kalimat terbuka yang berbentuk cerita.

e. Membahas arti persamaan yang ekuivalen.

f. Menyelesaikan persamaan menggunakan aturan :

8) Suatu persamaan tetap ekuivalen, jika kedua ruas ditambah / dikurangi dengan bilangan yang sama.

9) Suatu persamaan tetap ekuivalen, jika kedua ruas dikali/dibagi dengan bilangan yang sama.

g. Menggambar grafik himpunan penyelesaian dengan satu peubah.

4. Pertidaksamaan linier dengan satu peubah 
a. Mengingat pengertian pertidaksamaan dan lambangnya $\left(\leq, \geq_{,<,>)}\right.$

b. Membahas arti pertidaksamaan linier satu peubah.

c. Menetukan penyelesaian pertidaksamaan dengan mencari lebih dahulu penyelesaian persamaan.

d. Menentukan penyelesaian pertidaksamaan dengan aturan memperoleh pertidaksamaan yang ekuivalen.

10) Tanda pertidaksamaan tidak berubah, jika kedua ruas ditambah atau dikurangi dengan bilangan yang sama.

11) Tanda pertidaksamaan tidak berubah, jika kedua ruas dikurangi dengan bilangan positif yang sama.

12) Tanda pertidaksamaan berbalik, jika kedua ruas dikalikan dengan bilangan negatif yang sama.

e.Menggambar grafik himpunan penyelesaian pertidaksamaan pada garis bilangan.

f. Menyelesaikan soal-soal cerita yang menggunakan persamaan atau pertidaksamaan.

Berkaitan dengan peryataan bahwa matematika memepelajari tentang struktur yang terorganisasikan, konsep-konsep dalam matematika tersusun secara hirarki, terstruktur mulai dari konsep yang paling sederhana sampai pada konsep yang paling kompleks.

a. Konsep pada materi pengantar aljabar

Berbagai konsep pokok yang termuat di dalam materi pengantar aljabar di kelas I SMP, berikut disisipkan beberapa konsep yang esensial.

1) Bentuk aljabar

Bentuk aljabar $3 x+3$, yang mana $3 x$ merupakan suatu jumlah yang terdiri dari 3 suku yang masing-masing sukunya adalah $x$. Namun masih terdapatr siswa yang beranggapan keliru terhadap bentuk 3x. Anggapan tersebut antara lain : jika $x$ diganti dengan 7 , maka bentuk 2x berubah menjadi 27. anggapan ini dipengaruhi oleh pengetahuan siswa terhadap aritmetika. Tetapi perlu diingat bahwa aljabar itu sendiri merupakan perluasan atau generalisasi dari aritmetika.

2) Suku-suku sejenis

Dalam buku pelajaran matematika kelas I SMP (Depdikbud, 1993), diberikan contoh tentang suku-suku 
sejenis, seperti $6 x$ dan $-3 x, 3 y^{2}$ dan $7 y^{2}$, dan sebagainya. Sedangkan suku-suku yang tidak sejenis dicontohkan $6 x$ dan $3 y^{2}$ dan sebagainya. Berdasarkan contoh dan bukan contoh yang diberikan tersebut, dapat dikatakan bahwa suku-suku yang sejenis merupakan suku-suku yang mempunyai variabel dan pangkat variabel yang sama.

3) Kalimat terbuka

Kalimat terbuka adalah kalimat yang belum dapat ditentukan benar atau salahnya kalimat itu (Depdikbud, 1993), sedangkan pada kalimat terbuka akan memuat suatu simbol yang dapat diganti dengan satu atau lebih unsur dari suatu himpunan yang ditentukan. Konsep kalimat terbuka tersebut biasanya siswa berpikir bahwa kalimat terbuka itu suatu kalimat matematika yang bernilai salah, siswa berfikir demikian karena untuk yang diwakili variabelnya tak diketahui dan simbol yang ada pada kalimat terbuka ini dianggap mewakili bilangan lain yang bukan anggota pengganti.

4) Variabel

Simbol ...,,,$\infty$ dan $x$ pada bentuk $2+3=\ldots, 3 \times \diamond=9,8+$ $2=\infty$, dan $4 x+3=11$ masing-masing dinyatakan variabel atau peubah. Sedangkan pengganti simbol dinamakan konstanta, tanpa mengharuskan apakah unsur penggantinya menuntut kalimat itu menjadi kalimat benar. Selain itu, suatu simbol dapat diganti dengan sembarang anggota dari suatu himpunan semesta dinamakan variabel. Sejalan dengan itu, Soedjani (dalam Mulbar, 1998) menyatakan variabel ialah simbol yang menunjukkan anggota yang belum positif dalam suatu himpunan sedangkan konstanta adalah simbol yang menunjukkan anggota tertentu dalam suatu himpunan.

5) Persamaan

Persamaan adalah kalimat terbuka yang menyatakan hubungan sama dengan "=". Di kelas I SMP, hanya diberikan persamaan yang variabelnya berpangkat satu.

b. Prinsip pada pengantar aljabar

1) Sifat asosiatif

Sifat ini dikenal siswa sejak mempelajari aritmetika, secara umum pada sifat asosiatif berlaku $(a+b)+c=a+(b+c)$. Demikian pula yang berlaku pada aljabar, misalnya $(2 x+$ $3 y)+2 y$, akan bernilai sama dengan $2 x+5 y$. sifat ini akan 
banyak membantu dalam penyelesaian soal-soal yang berkaitan dengan persamaan.

2) Sifat distributif

Pada dasarnya sifat ini menyatakan perkalian sebagai jumlah atau selisih. Perkalian ini dapat dilihat dari bentuk umum dari sifat distributif sebagai berikut :

i) $a(b+c)=a \cdot b+a \cdot c$ dan

ii) $a(b-c)=a \cdot b-a \cdot c$

3) Sifat equivalen pada persamaan

Sifat equivalen pada suatu persamaan berlaku jika hanya kalau ruas suatu persamaan masing-masing ditambah atau dikurangi dengan suatu bilangan yang sama, maka diperoleh persamaan baru yang himpunan penyelesaiannya sama dengan himpunan penyelesaian semula (Pandojo \& Moesono, 1993). Kedua persamaan itu dikatakan ekuivalen (setara) dan dinyatakan dengan simbol " $\Leftrightarrow "$ (dibaca : ekuivalen dengan). Sifat equivalen pada persamaan ini berlaku juga untuk persamaan yang kedua ruasnya diwarnai operasi perkalian atau pembagian dengan bilangan yang sama.

4) Sifat ketidaksamaan

Pandojo dan Moesono (1993) menyatakan bahwa sifat ketidaksamaan dengan pernyataan "untuk setiap dua bilangan a dan $b$ hanya berlaku suatu hubungan yaitu: $a<b$, atau $a>b$. Sifat lain dari sifat ketidaksamaan yaitu Jika $a, b, c$ bilangan real, dan $a<b$, maka

i) $a+c<b+c$

ii) $a-c<b-c$

iii) $\mathrm{ca}<\mathrm{cb}$, jika c positif

iv) $\mathrm{ca}>\mathrm{cb}$, jika $\mathrm{c}$ negatif

v) $\frac{a}{c}<\frac{b}{c}$, jika c positif

vi) $\frac{a}{c}>\frac{b}{c}$, jika negatif

Pengetahuan mengenai sifat-sifat tersebut sangat diperlukan untuk mempelajari dan memahami materi pertidaksamaan sebagai perluasan dari materi persamaan.

\section{Penutup}

1. Wujud dari kesulitan siswa dalam menggunakan konsep antara lain : 
a. Ketidakmampuan untuk mengingat nama-nama secara lisan.

b. Ketidakmampuan menyatakan arti dari istilah yang mewakili konsep tertentu.

c. Ketidakmampuan untuk mengingat satu atau lebih kondisi yang diperlukan bagi suatu objek untuk dinyatakan dengan istilah yang mewakilinya.

d. Ketidakmampuan untuk mengingat suatu kondisi yang cukup bagi suatu objek untuk dinyatakan dengan istilah yang mewakili konsep tersebut.

e. Tidak dapat mengelompokkan objek sebagai contoh suatu konsep dari objek yang bukan contohnya.

f. Ketidakmampuan untuk menyimpulkan informasi dari suatu konsep yang diberikan.

2. Wujud dari kesulitan siswa dalam menggunakan prinsip, antara lain :

a. Tidak mampu melakukan kegiatan penemuan tentang sesuatu dan teliti dalam melakukan perhitungan atau operasi aljabar.

b. Ketidakmampuan siswa untuk menentukan faktor yang relevan dan akibatnya tidak mampu mengabstraksikan pola-pola.

c. Siswa dapat menyatakan suatu prinsip tetapi tidak dapat mengutarakan artinya dan tidak dapat menerapkan prinsip tersebut.

\section{DAFTAR PUSTAKA}

Depdikbud, 1993, Kurikulum SLTP GBBP Pendidikan Matematika, Jakarta.

Hudoyo, Herman, 1988, Mengajar Belajar Matematika, Depdikbud, Dirjen Dikti P2LPTK, Jakarta.

Mulbar, Usman, 1988, Beberapa kesulitan siswa dalam belajar konsep dan prinsip pada pengamatan aljabar di SLTP, jurnal transformasi, vol.113 IKIP Ujung Pandang. Pandojo dan Moesono, 1993, Matematika untuk Sekolah Lanjutan Tingkat Pertama Kelas I. Depdikbud, Jakarta. 